Никола 3. Маринковић*

Универзитет у Београду

Филолошки факултет

Докторске студије

https://doi.org/10.18485/ai_beckovic.2019.ch6

821.163.41.09-1 Бећковић М.

\title{
ЛИРИКА НЕНАЧЕТЕ ДУШЕ: ПОЕТИЧКЕ ТРАНСФОРМАЦИЈЕ У ЗБИРКАМА ТРИ ПОЕМЕ И ПРАХУ ОЦА ПОЕЗИЈЕ У КОНТЕКСТУ БЕЋКОВИЋЕВЕ ПОЕЗИЈЕ
}

У раду испитујемо поетичке трансформације које су од почетака Бећковићевог опуса водиле до молитвеног искуства у књигама Три поеме (2015) и Праху оца поезије (2016). Поменуте књиге ћемо анализирати и у контексту поетичких континуитета и промена у односу на претходне Бећковићеве поеме или песме. Испитаћемо и на који начин религиозна тематика ових књига резонира са културолошким импликацијама Бећковићеве поезије из претходних фаза.

Кључне речи: Матија Бећковић, поетика, поетичке трансформације, поеме

У беседи на додели Његошеве награде 1998. године, Матија Бећковић је рекао да је оно његошевско „што се не шће у ланце везивати" (Бећковић 1998) сам језик. Говору на додели награде аутопоетички претходе вишеструко прештампане „Белешке” из књиге поема Рече ми

\footnotetext{
* marinkovic.nikola@mail.ru

** Рад је настао у оквиру НИП 178026 „Проучаваоци књижевности у српској култури друге половине двадесетог века" који финансира Министарство просвете, науке и технолошког развоја Републике Србије.
} 
један чоек (1970) у којима се читав културни и историјски идентитет народа уписује у језик: „Језик је памћење народа које није ни мало на кратко. У језику је акумулирана мудрост времена, све што је требало запамтити." (Бећковић 1986: 341) Такође, Бећковићеве збирке у дијахронијском низу реализују особен и препознатљив поетички модел употребе језика, али увек са извесним променама које доприносе унутрашњем разлиставању његове поетике, у распону од Вере Павладољске (1962) до Три поеме (2015) и Праху оияа поезије (2016).

Бећковићев исказ о језику има вишеструке импликације. Он се може читати као извесна врста метакњижевноисторијског става о снази романтичарске употребе језика, која у контексту његове песничке генерације (у виду имамо песнике који су ревитализовали поему, уз Бећковића то су свакако Бранислав Петровић и Љубомир Симовић) значи и известан отклон од неосимболистичке и модернистичке поезије њихових претходника. ${ }^{1}$ Оба поетичка правца у даљем развоју српске поезије друге половине 20. века имају своје представнике, од којих су неки и даље делатни, па се Бећковићев исказ може тумачити и као накнадни одговор на оспоравања уметничке вредности овог песничког правца у контексту модерне књижевности.

У културноисторијском контексту ослобођење језика аналогно је националној еманципацији. Контекст

1 У делу критике и науке о књижевности овај отклон тумачен је као поетички умор: „Умор од урбанога језика и засићеност модерним говорним, а још више писаним клишеима, активирали су и покренули ту траку из дјетињства као траку отпора и тачку ослонца." (Делић 2012: 25) Отпор и ослонац, као термини које Делић помиње, указују и на превратнички потенцијал Бећковићеве поетике, која у тренутку када се појављује, експлицитно најављује и промену поетичких парадигми. (Видети нпр. ране песме „Матија Бећковић” и „Доста је било”, Бећковић 1980: 14-19) 
места и времена у којем је исказ изречен сугерише вишеструку испреплетаност културноисторијских представа које су у корену Бећковићеве особене песничке поруке и (друштвено-политичке) стварности у којој његова поезија настаје, као што је случај са поемама „Не дај се јуначки сине”, објављене у књизи Рече ми један чоек (1970) и Ћераћемо се још (1996).

У интеракцији ова два могућа значења Бећковићевог исказа остварује се сложени поетички и културни план који засвођује његову поезију. Културнополитички оквири у којима је књижевни језик требало да функционише у 20. веку вишеструко су били нормирани: од београдског књижевног стила и њему аналогне песничке генерације (а којој су наследовали послератни модернисти) преко бирократизације језика након Другог светског рата као особеног начина да се у комуникацији посредује инстанца моћи, ${ }^{2}$ па све до нормативног насиља над дијалектима који су чинили основу његошевског језика крајем 20. и почетком 21. века у оквиру пројекта октроисања црногорског књижевно-језичког стандарда. ${ }^{3}$

Млади Бећковић у књигама Вера Павладољска (1962) и Метак луталииа (1963) у односу на наслеђене поетичке норме претходне песничке генерације заговара одступање у језик који ће касније, у свом радикално дијалектизованом виду препознати као „деструктиван и јеретичан” (Бећковић 1986: 342) а његове мале форме као поља слободе. Док у Вери Павладољској усмено језичко наслеђе није присутно у значајнијој мери, то се његов

2 у „Белешкама” у књизи Рече ми један чоек Бећковић за песнички језик којим се служи (а чији дијалекатски прототип везује за говор Роваца), истиче да се на њему „не може изражавати ништа дневно и плитко, ништа једносмерно и привремено, никакав официјелни оптимизам". (Бећковић 1986: 342)

3 Исцрпан преглед социолингвистичке ситуације у Црној Гори видети у Стојановић 2016: 339-414). 
удео увећава у Метку луталиนии и збирци Тако је говорио Матија (1965). У том контексту, рана Бећковићева песма „Сонет” може се читати као комбинација малих усмених облика у једној строгој песничкој форми што има и метапоетичку вредност. Борба за верност речима и запостављеним говорним и језичким облицима присутна је и у другим раним Бећковићевим песмама, попут „Доста је било":

Употребимо све речи јер је сан сваке речи да буде употребљена

И избављена из речника и писаћих машина. (Бећковић 1980: 16)

Самопрокламовану слободу, која истовремено тежи ослобађању и језика и песника (посредно и реципијената песничког текста и преко њих читаве културе), Бећковић проналази у окретању народном говору који и даље чува обиље речи које се у његовој поезији неометано ослобађају и рекреирају. У том поетичком кретању Рече ми један чоек означава прво Бећковићево освајање слободе језика, којом досеже до архетипских слојева, што је посебно видљиво уколико се његове епске поеме посматрају у заокруженој целини коју чине Рече ми један чоек, Међа Вука Манитога (1976) и Леле и куку (1978).

Песничко уобличавање новог, на дијалекту заснованог говора у поеми „Рече ми један чоек”, и њој наследујућој „Не дај се јуначки сине” производи асоцијативно богатство карневализацијских језичких облика и особени каталог ругалачких речи. Окретање дијалекатском идиому свој израз је пронашло у набрајању, ругању и лелеку, али и у тужбаличком стиху у који је уписана гротеска, што је комбинација која изворно усмено-књижевни облик жанровски модернизује. Низ поема испе- 
ван је на том трагу у готово градативном расту гротескног потенцијала: „Унук Алексе Маринкова плаче над Црном Гором”, „Кукавица”, сходно чему је већ у „Лелек мене” заједница чијим говором пева Бећковић готово онтолошки немогућа:

Њин Падиша мртав кући дође,

А наш Царе из гроба не уста.

Не одосмо намо ни онамо

Полумјесец више не остаде.

Крст на Небу никад не изгрија.

Остадосмо у збјег без Турака.

Пећине нам постадоше куће. (Бећковић 1986: 301)

Преображени усмени облици које Бећковић употребљава у свом изворном књижевном контексту преносе колективно, завештано знање. ${ }^{4}$ Усмени певач је „памтио и чувао средства одржавања културног континуитета као и друштвене корене ове културе”. (Хавелок 1991: 43) У конкретној Бећковићевој поеми, то знање губи смисао јер је колектив обликован као парадоксалан. Говорници Бећковићевог језика нису наследници сакралног већ нежељеног завета, гротескни у својој измештеној, премда наслеђеној и препознатљивој појавности:

Посвећени, љути, задивљали,

А докони, строги и свечани.

Због великих брига које брине

Свако се чини велики је! (Бећковић 1986: 303)

Међу бројним лирским сведочењима о увиру епске традиције српског народа и његовог заветног иденти-

4 Епске форме које Бећковић рекреира изворно биле су преносилац колективног знања, што се у теорији препознаје као „културна улога стихованог језика”. (Хавелок 1991: 42). 
тета, Бећковићева међу реткима акцентују управо тај несклад између савременог и завештаног идентитета:

„Моја Црна и све Црња Горо,

Нема већег несмисла и жртве

Него твоје - за завјет залудњи.

Страшно ли је што те више нема,

А страшније што и сад постојиш. (Исто: 310 )

Може се закључити да поеме „Богојављење” и „Лелек мене" представљају врхунац ове поетичке градације. Преобликовани формулативни обрасци који преносе колективни идентитет наместо свог првобитног садржаја посредују потпуну празнину ${ }^{5}$ која не само да је последица или знак модерности већ и предуслов песничког novum-a. Уместо земље која је „чувар великог националног мита" (Исто: 343) у Бећковићевој поезији се конфигурише искуство земље Шћепана Малог, једине земље на свету у којој „постоје горди конобари,/ Подворници с хајдучким брцима" (Исто: 321 ).

Трилогија поема зато се закономерно завршава „Вучјом тужбалицом” из књиге Леле и куку, као епилогом једног дужег песничког силажења у колективно памћење ослобађањем речи и облика. Ослобођени облици нису само отворили простор певања мимо искуства савремене лирике већ су и сами ослобођени свог мнемокултурног

5 Нихилистички моменат, који се може наслутити у дубокој позадини обесмишљених мнемотехничких облика, није био непознат Његошевом песничком искуству, највише у Лажном изару Шћепану Малом (1851) у којем песник Горског вијениа наговештава замирање херојског света: „Крај херојског света, који он оглашава, обележава наступање новог историјског времена, отвореног за потоње стадијуме нихилизма. Лажни цар Шћепан Мали оличава временско прескакање из једног реда историјских чинова у други историјски поредак, он је слика прелаза из једне у другу историју." (Ломпар 2008: 272) 
контекста, чиме постају ефектан песнички реквизит за конфигурисање бившег епског колектива у савременом духу несавременом формом.

Од вековне борбе за завет остало је још само сукобљавање зарад сукобљавања, нека врста осамостаљеног агона као первертираног епског квалитета - што је најдубљи лирски увид књиге Ћераћемо се још (1996). Заветни језик је приближен сатири, враћајући се из предањског у савремено друштво, у максимализацији својих карневализацијских потенцијала. Уметничко искуство „Богојављења”, као сусрета колектива са метафизичким кореном који је одбачен, у познатој сатиричкој поеми пројектован је и у будуће време:

„Ћераћемо се још

Са Богом и људима

Сваки у Бога дан

С Богом се ћерати и рвати

То је право ћерање

А с ким год се ћераш

С њим се ћераш! (Бећковић 1998: 128)

Од модернистичко-поетичке неслободе из ране песме „Доста је било”, песник је усложњавањем поетике стигао до неслободе обесмишљеног завета, који још претрајава искључиво као осамостаљена и одметнута форма, јер „Ћерања има/ Ако разлога нема”. (Исто: 132) Међутим, жанровска ограничења сатире 6 имплицирају да даље развијање сатиричних и иронијских потенцијала не би могло донети нови поетички преображај. Двокњижје Кад будем млађи (2007) и Кад будем још млађи (2012) не

6 Пошто је имплицитни циљ сатире ругалачки, односно да „исмије људске слабости, мане и гулупости, њен тон ријетко кад тежи таквој свечаној и патетичној осуди у којој би се његов интензитет подигао до правог трагичког осјећања”. (Лешић 2001: 745) 
поништава трагику „Лелека мене”, односно не релативизује удес узалудности савремене колективне егзистенције јер нема катарзично већ ругалачко дејство.

Могући искорак поетички је наслућен тамо где је лични песнички језик већ бивао трансцендиран, али у мери која није значајније утицала на укупни лик Бећковићеве поезије. У питању је неколико песама које тематизују културно-историјске теме везане за хришћанско наслеђе српске културе. Оне се условно могу и тематски разделити. Међу песме у којима је општа хришћанска симболика претежнија над национално историјском спадале би „Путовање у Свету земљу уочи двехиљадитог Христовог рођендана” и „Слово”, издвајају се и три хиландарске песме „Богородица Тројеручица”, „Трорука чудотворка”, „Богородица Тројеручица заштитница српских песника”, а ту свакако спадају „На гробу оца Јустина”, „Прича о Светом Сави” и „Косово поље”.

У поменутим песмама песник је мењао свој израз, отвара језик за елементе молитвеног говора. Карактеристике покајног молитвеног тона, премда у ширем контексту сличне емотивном и семантичком језгру тужбалица, фигуром Бога као адресата песничке комуникације остварују нови квалитет. У овим песмама Бећковић је „активирао основне вредности српске културе”, и испитао „шире културно-националне могућности”. (Јовановић 2002: 121) Међутим, молитвено песничко искуство, подједнако удаљено и од сатиричних и од епских квалитета Бећковићевих поема, није било реактивирано све до рецентнијих песничких књига. Поетичке позиције освојене у поменутим песмама у дијахронијској

7 Хиландар као песничка тема је једна од ретких непосредних поетичких спојница између различитих песничких генерација у српској књижевности друге половине 20. века. Бећковић се овим трима песмама сврстава у низ песника које чине Васко Попа, Миодраг Павловић, Љубомир Симовић, Слободан Марковић и многи други. 
перспективи испостављају се као корен који је своје плодове дао тек у Три поеме (2016).

Дијалектика поетичких сличности и разлика, карактеристична за прелаз из прве Бећковићеве фазу у другу, присутна је и овде. Употреба наслеђених облика препознаје се у литургијском понављању молитвеног дистиха на крају сваке дуже целине (које би се пре могле назвати молитвеним песмама) поема „Господе помилуј” и „Слава теби Боже”. У тексту се уочава и карактеристично набрајање асоцијативно сличних речи, али не и ругалачких, што показује на који начин високомиметски жанр утиче на Бећковићев песнички језик. Семантички је наглашена и особено хришћанска метафизичка туга за свет (у име онога што није од „овога света”: „А песнику је сваком отаџбина / Она непозната далека једина / Чији је грађанин једино и био”; Бећковић 2015: 52), али не и тужбалички лелек. Сви ритмички и стилски импулси врхуне се у молитвеној реторици, а која функционише и као песничко-комуникативна могућност излаза из затвореног круга карневализацијског говора.

У традицијском контексту, овај песнички чин свакако је у дослуху са традицијом молитвене песме у модерној српској књижевности која сеже све до Његошевих метафизичких песама, а ова веза посебно је значајна у контексту Бећковићевог песничког језика. Његове молитвене поеме су освећивање једног изграђеног поетског идиома, и у том освећивању се види његов преображај, сличност која је истовремено и различитост. Тиме је начињен квалитативно нов субверзивни искорак, у контрасту са налогом времена: у постхуманистичком тренутку наглашене детрадиционализације, реактивирање молитвене реторике није само аутономни песнички чин већ позив на преосмишљавање различитости кроз концепт саборности, као далекосежан, и од прве фазе Бећковићевој песништва битно удаљен културни чин: 

А у језику сваког национа
Сви су језици и сва васиона
Створени због неког разлога и смисла
Као делови божјега промисла (Исто: 52)

Продуктивност нове поетичке тенденције Бећковић је потврдио и књигом Праху оиа поезије (2016), коју жанровски није лако класификовати. У исцрпном предговору Милован Данојлић пише да би се овај „невелики спев” могао назвати „службом у црквеном значењу тог појма” (Данојлић 2016: VII), док у продужетку текста спомиње „Матијину оду, или службу духовном великану” (Исто). Попут поеме, коју Бећковић најчешће користи, и спев је дугачка форма са приповедним потенцијалом, док црквена служба, као врло прецизан богослужбени текст само делимично користи наративне елементе јер по примарној функцији припада шире одређеном молитвеном жанру ${ }^{8}$. Ода, античка песничка врста, слави јунака као узорити пример за шири колектив. Све наведене жанровске особине присутне су у структури новог песничког текста Матије Бећковића.

Текст Праху оиа поезије структурно је организован на основу елемената из Његошеве биографије, али је њихов уплив у текст ограничен преклапањем особености поеме и црквене службе. Биографски елементи су првенствено повод да се нагласе основне смисаоне линије песничког текста и да му омогуће дубљу кохерентност. Такође,

8 Молитвени жанр је основни елемент шире скупине облика који се у савременој теорији одређују као „химнографски жанрови са молитвом као својим примордијалним и примогенитурним елементом" (Кончаревић 2015: 51) Лексички ниво је „једна од најважнијих компоненти језичке организације молитвене", (Исто: 267) а „стилске одлике текста молитвене песме манифестују се пре свега у интензивном присуству јединица из тематске групе 'православна сакрално-богослужбена лексика"'. (Исто: 268) 
наративни елементи су релативно слободно распоређени и омогућавају даљу асоцијативну разраду у разноликим правцима универзализације семантичког слоја. Носећи мотиви Његошеве биографије прерастају у универзалне песничке теме односа између Творца и природе, природе и песника и језика и песника, који скупно увиру у семантику односа творца поезије и Творца света.

Преплитање елемената различитих песничких врста указује и на нове начине којима се у Бећковићеву поезију уписује модерно песничко искуство: хибридизацијом жанрова која, што је посебно важно за интегритет молитвеног тона, не прекорачује границе високомиметског говора. Истовремено, наслеђене стилске доминанте Бећковићеве поетике као да су исувише снажне да би могле да се уоквире строжим строфичним или версификацијским облицима јер Бећковићев песнички језик готово у свакој прилици превладава границе традиционалних песничких форми.

Милован Данојлић у већ помињаном предговору овој књизи пише: „Матија се у овој, његошевској ковачници, размахао са оновременом, романтичарском необузданошћу, следујући архаизме богослужбене реторике Луче." (Данојлић 2016: XVII) Другим речима, Његошева фигура и њен културноисторијски смисао конфигурисани су у координатама вуковског језика због чега Бећковић доследно прати Његошеве методе обликовања сложенијих и апстрактнијих појмова из високе, махом религијске сфере. На ту стилску и идиомску основу постављени су главни јунаци овог хибридног песничког остварења: Његош, језик и Бог, у међузависан однос чију константу представља недокучивост њихових појединачних природа.

Овим мотивом Бећковић започиње свој службу/ поему и показује да у његовом песничком разумевању Његоша биографија (тајне које знамо), није оно што је и суштинско код класика српске књижевности (тајна духа коју не знамо): 
Нема тајне коју о теби не знамо

Ал Тајну твог духа још одгонетамо. (Бећковић 2016: 7)

Његошу, као творцу песничког космоса, приписују се атрибути Бога („А највећа си ти сам себи био / Да си који јеси ни ти ниси знао."; Исто) а несазнатљивост Његошевог духа преноси се и на његова дела:

А нико не зна вредност остварења

За које толико паде поколења. (Исто: 11)

Примарно значење стихова упућује на Горски вијенаи и национално-ангажовани семантички слој овог спева, али се може проширити и на Његошеву историјску заоставштину, Црну Гору као државу српског народа. На тај начин се овај текст отвара и ка критици савремености. Овај тематски слој на почетку је само назначен, но како се лирско приповедање развија, то се убрзава и тематско прилажење савремености као исход самог певања о Његошу и поводом њега, па је савременост главни мотив у завршним одељцима. Ово семантичко кретање омогућава и трансцендирање жанровских граница па се покајни делови црквене службе преобликују у покорне тонове упућене савременим Његошевим сународницима:

Више нас нема у реалном свету

Али нас има свуд по интернету

На профилима и на сајтовима

По фесјбуцима и по порталима

Потврдили смо себе дигитално

А у стварности нас нема ни случајно. (Исто: 91)

Покорни тон, који, међутим, остаје на граници која би омогућавала да се говори и о сатири, делове текста који адресирају савремене Црногорце приближава поемама 
„Лелек мене” и „Вучја тужбалица”. Блискост је остварена акцентовањем испражњености савремено дефинисаног идентитета Црне Горе од Његошевог културно-идентитетског програма:

Дође и оно доба никадније

Свако постаде баш оно што није

Помислише и твоји потомци

Ако нису Срби да су Црногорци

Кад којега упитају ко је

Одговара да је све оно што није. (Исто: 85)

Истовремено са покудом савремености, Његош је Бећковићу повод за похвалу културне прошлости, и то као прошлости језика:

Кад Срби почеше ником поницати

И предаде се сваки свакијати

Језик се не шће у ланце везати

Него се горских венаца дохвати

И окатуни се у каменом скиту. (Исто: 15)

Аутоцитат из беседе приликом добијања Његошеве награде показује да је текст Праху оца поезије уписан један континуитет разумевања традиције који се врхуни у слављењу њеног темељног медијума - језика. Тајна Његошеве појаве зато се открива као деловање језика, који, у недостатку народа, има његове особине. Значења језика досежу и метафизичке тонове када се, као предуслов Његошеве појаве, језик стапа са фигуром Бога („У језику се саздатељ сакрио / И цео стао и невидљив био.”; Исто: 65) а фигура Бога са фигуром песника:

Од једног песника су постали песници

Од једног језика сви други језици

Од оног којим је свемир говорио 
Нема га али се није изгубио

Једна књига је родила остале

А које није нису постојале. (Исто: 67)

Фигура Бога и спомен Библије призивају у текст Праху оца поезије и цитате из Старог и Новог Завета, који додатно доприносе универзализацији Његошеве фигуре и њеном прерастању националних оквира. Тако се парафразирањем Христових речи дубље мотивише надисторијска неминовност Његошеве појаве:

Да реч не рече гласноговорниче

Камење би почело да виче

Да си занемио и закаменио

Сваки би те камен заменио. (Исто: 23)

Фигура ловћенског песника тако је поистовећена са још једном библијском фигуром - пророком. Тиме се, међутим, и даље не исцрпљује недокучивост Његошеве појаве и њеног историјског смисла већ се тајна продубљује проширивањем контекста њеног настанка. Проширивање поља тајновитости маркирано је неологизмима и архаизмима који се римују са (алузивно-цитатним, јер Бећковић сваки директни цитат преобликује у индиректни) рефреном на крају сваког одељка („Небесима осијан песниче”). У том римовању, идентичан претпоследњи стих („Да, свагда ми драги...”) увек се допуњава различитом, премда морфолошки сродном речју која у себи сажима смисао одељка који завршава и описује један од многобројних Његошевих ликова. Тиме се добија стилско-реторички низ од четрдесет пет Његошевих епитета који су производ Бећковићеве поетичке радионице или су наслеђени традицијом: дожудник, неженик, сажижник, првописац, причесник, племеник, лучоноша, космотворац и сл., а у том низу налази се и једна ресемантизована лексема - језичник. 
У црквенословенском и старословенском писменом наслеђу поменута лексема означава паганина, нехришћанина кога тек треба просветити. У овом случају, одабир ове речи због ефекта римовања директно мења њено значење у правцу Његошевог творачког печата који је утиснуо у српски језик. Стога овај пример у коначници показује колико је Праху оца поезије првенствено и пресудно Бећковићева песничка творевина. У својим најособенијим моментима она не само да осветљује и оспољава тајну Његошеве појаве, већ потврђује и проширује могућности Бећковићеве поезије.

У дијахронијској перспективи од збирке Метак луталица (1963) до Праху оца поезије (2016) Бећковићева поезија показује виталност у непрекидном превазилажењу традицијских образаца зарад њиховог потврђивања. Већ са поемом Рече ми један чоек (1970) песник је свесно преобликовао дотадашњи поетички лик и обогатио га особеним третманом дијалекатског говора који му је омогућио да посегне и за употребом образаца усмене културе. Сатирички потенцијал Бећковић је остварио у књигама Ћераћемо се још (1996), Кад будем млађи (2007) и Кад будем још млађи (2012), а у књигама Три поеме (2015) и Праху оцза поезије (2016) подузео је значајнији поетички преображај. На овај преображај највише је утицао молитвени говор и аналогни систем жанровских образаца. У контексту проширивања семантичких веза са ширим слојевима културе и опевања историјских процеса у њој, као и потребе да увек и изнова говори о савремености, ова промена била је у извесном смислу и потребна. Отуда се о последњој Бећковићевој фази може говорити и као о посебној, могуће и недовршеној. Лирско Ја његове поезије и даље остаје, као лирски субјект Три поеме, душа „још неначета а испрепадана" (Бећковић 2015: 11) макар стога што у богатом наслеђу српског језика увек налази неистражене или недовољно истражене изворе обликовања зановљеног поетског говора. 


\section{ЛИТЕРАТУРА}

Бећковић 1980: М. Бећковић, Два света, Београд: Просвета.

Бећковић 1986²: М. Бећковић, Поеме, Београд: Српска књижевна задруга.

Бећковић 19983: М. Бећковић, Ћераћемо се још, Подгорица Будва: Октоих - Град театар.

Бећковић 1998: M. Beckovic, Beseda Matije Beckovica na urucenju Njegoseve nagrade, Naša borba, http://www.yurope.com/nasaborba/arhiva/Apr98/1504/1504_27.НTM, приступљено 1. 7. 2019.

Бећковић 2015: М. Бећковић, Три поеме, Београд: Српска књижевна задруга.

Бећковић 2016: М. Бећковић, Праху оияа поезије, Београд: Српска књижевна задруга.

Данојлић 2016: М. Данојлић, Служба Његошу, у: М. Бећковић, Праху оияа поезије, Београд: Српска књижевна задруга, VII-XIX.

Делић 2012: J. Делић, Аутопоетички тренуци Матије Бећковића језичка самосвијест, у: Ј. Делић, Д. Хамовић (ур.), О песмама, поемама и поетици Матије Бећковића, Београд - Требиње: Институт за књижевност и уметност - Учитељски факултет Универзитета у Београду - Дучићеве вечери поезије, 17-48.

Јовановић 2002: А. Јовановић, Хришћанске песме Матије Бећковића, у: Д. Хамовић (ур.), Матија Бећковић, песник, Краљево: Народна библиотека „Стефан Првовенчани”, 119-133.

Кончаревић 2015: К. Кончаревић, Поглед у теолингвистику. Београд: Јасен.

Лешић 2001: Z. Lešić, Satira, u: D. Živković, Rečnik književnih termina (fototipsko izdanje), Banjaluka: Romanov.

Ломпар 2008²: М. Ломпар, Његош и модерна, Београд: Нолит.

Стојановић 2016: Ј. Стојановић, Пут српског језика и писма, Београд: Српска књижевна задруга.

Хавелок 1991: E. A. Havelok, Muza uči da piše, Novi Sad: Svetovi. 
Nikola Marinković

\author{
LIRICS OF A VIRGIN SOUL: \\ POETICAL SHIFTS IN COLLECTIONS \\ OF POEMS THREE POEMS AND TO THE \\ REMAINS OF THE FATHER OF THE POETRY \\ IN CONTEXT OF THE BECKOVIC'S OUVRE
}

From the very beginning, Beckovic's poetry has been showing specific vitality. Its everlasting poetical power to transcend inherited lyrical forms can be traced from early collection of poems Stray bullet (1963) up to the To the Remains of the Father of the Poetry (2016). Again and again, Beckovic succeeds to transform and enrich his poetical identity. Most notably, he managed to do that due to the specific use of dialect speech from the poem I was told by a man (1970) to the Lele I kuku (1980).

Liturgical discourse and prayer as a genre motivated next significant shift in his poetry. Late collections of poems, Three poems (2015) and To the Remains of the Father of the Poetry (2016) widened cultural and semantic values of Beckovic's poetry. It gave him new ways to sing about contemporary issues as well as to maintain his conscious and very individual loyalty to the leading traditions of Serbian poetry that stretches back to the medieval literature, via romanticist poetics of Peter Petrovic Njegos, to whom the afore mentioned collection of poems from 2016 is dedicated to.

Key words: Matija Beckovic, individual poetics, poetical shifts, poems 